\section{Géneros}

Multidisciplinary Journal of Gender Studies

\section{Hipatia Press www.hipatiapress.com}

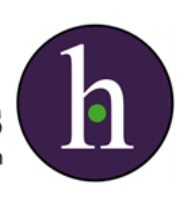

Instructions for authors, subscriptions and further details:

http://generos.hipatiapress.com

\title{
Factors Associated with Domestic Violence against Rural Bangladeshi Women
}

Anisur Rahman Khan ${ }^{1}$

1) Department of Social Relations, East West University, Bangladesh.

Date of publication: February $25^{\text {th }}, 2017$

Edition period: February - June 2017

To cite this article: Khan, A. R. (2017). Factors Associated with Domestic Violence against Rural Bangladeshi Women. Multidisciplinary Journal of Gender Studies, 6(1), 1208-1230. doi: 10.17583/generos.2017.2085

To link this article: http://dx.doi.org/10.17583/generos.2017.2085

\section{PLEASE SCROLL DOWN FOR ARTICLE}

The terms and conditions of use are related to the Open Journal System and to Creative Commons Attribution License (CC-BY). 


\section{Factors Associated with \\ Domestic Violence against \\ Rural Bangladeshi Women}

Anisur Rahman Khan

East West University

\section{Abstract}

This study examines the causes of domestic violence against rural Bangladeshi women. By drawing on thirty-nine semi-structured in-depth interviews through phenomenological approach of qualitative study, conducted in eight rural settings in Netrokona and Mymensingh districts, it was found that every experience of the women with domestic violence has a context or contexts. Broadly, the prominent causes of domestic violence were identified as dowry-demand, polygamy and extramarital relations, in-laws syndrome, childless and sonless state, questioning husbands, and not meeting the husbands' and in-laws' expectations. Patriarchal structure and system of the society are broadly and dominantly interwoven in every factor of domestic violence. Making structural changes to women's subordination is the most important strategic response to eliminate or prevent domestic violence from the society.

Keywords: Bangladesh, domestic violence against women, factors, patriarchy, women's subordination 


\title{
Factores Asociados a la
}

\section{Violencia Doméstica contra las Mujeres Rurales Bangladesís}

\author{
Anisur Rahman Khan \\ East West University
}

\section{Resumen}

Este estudio examina las causas de la violencia doméstica contra las mujeres rurales de Bangladesh. A partir de treinta y nueve entrevistas semi-estructuradas a través del enfoque fenomenológico del estudio cualitativo, realizado en ocho contextos rurales de los distritos de Netrokona y Mymensingh, se encontró que cada experiencia de violencia doméstica tiene un contexto o contextos. En términos generales, las causas prominentes de la violencia doméstica se identificaron como la demanda de dote, la poligamia y las relaciones extramatrimoniales, el síndrome de los cónyuges, no tener hijos, el cuestionamiento del marido y no cumplir con las expectativas de los maridos y las leyes. La estructura patriarcal y el sistema de la sociedad están ampliamente y predominantemente entretejidos en cada factor de violencia doméstica. Hacer cambios estructurales a la subordinación de las mujeres es la respuesta estratégica más importante para eliminar o prevenir la violencia doméstica de la sociedad.

Palabras clave: Bangladesh, violencia domestica contra las mujeres, factores, patriarcado, subordinación de las mujeres 


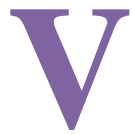

iolence against women is a pervasive form of abuse which has spread over the entire world irrespective of cultural, geographic, social, or economic demarcations (Naved and Persson, 2005). It is so widely and commonly spread irrespective of country and society that it is considered by some experts as normal (Levy, 2008). It is like a global epidemic which serves as a tool of the violation of human rights (Amnesty International, 2004). On the other hand, domestic violence consists of physical, sexual, psychological and controlling behaviour against an intimate partner (Esquivel-Santoveña, Lambert and Hamel, 2013). Very specifically, domestic violence or violence that takes place at home accounts for a major portion of the violence that occurs worldwide against women (Perillia, Lippy, Rosales, and Serrata, 2011). Specifically, domestic violence which is perpetrated by the husband cuts across socio-economic, religious, and ethnic boarders (Richardson, Coid, Petruckevitch, Chung, Moorey, and Feder, 2002). It is a dangerous practice and it is often said that the safest palace for men is the home; alternatively, the home is the least safe place for women (Edwards, 1989). Research indicates that domestic violence is the most pervasive and widespread problem around the world (EsquivelSantoveña, Lambert and Hamel, 2013). It is generally estimated that one in four women in their lifetime and between one in ten women experience violence annually (Women's Aid, 2009). Millions of women are injured and thousands are killed each year as a result of domestic violence (Hattery, 2009). Although various forms of violence are perpetrated against women, the state of domestic violence perpetrated by husbands is very serious in Bangladesh. It is often treated as a part of the normative order in social relations and only comes to light if it results in serious injury. In fact, many women tend to accept it as a reality of their life (Siddiqi, 2006). Such violence is one of the most extorting cultural practices in all times in Bangladesh (Bhuiya, Sharmin, and Hanifi, 2003). As a public policy problem, the government of Bangladesh has made strides in harmonising the national legislation with international commitments to protecting the rights of women and eliminating violence against them (Johnston and Naved, 2008). Despite having interventions from the government for the protection of women in Bangladesh, domestic violence is continuing and in some cases increasing day by day (Khatun and Rahman, 2012). Different available 


\section{Khan - Violence Against Rural Bangladeshi Women}

empirical studies in Bangladesh reported high rates of various forms of wife abuse ranging from 39 percent to 79 percent (Schular, Hashemi, Riley, and Akhter, 1996; Koenig, Ahmed, Hossain, and Khorshed, 2003; Bates, Schular, Islam, and Islam, 2004; Salam, Alim and Noguchi, 2006; Naved, 2013). However, empirical works on domestic violence against women in the context of Bangladesh are not only limited, but most of the available works are based on positivist approach which makes it difficult to grasp indepth, thick and inclusive picture of domestic violence. In fact, quantitative methods and survey approaches, in particular, are not sensitive to women's experiences and concerns (Skinner, Hester, and Malos, 2005). Moreover, the dearth of subjective understanding of various causes of domestic violence is one of the major gaps of the existing literature. Notably, a vital part of preventing a social problem is to have an understanding of what causes it (Crowell and Burges, 1996). In this research, I have made an attempt to explore the causes or the contexts of domestic violence against rural Bangladeshi women perpetrated by their husbands.

\section{Research Design}

This paper is an outcome of a broader study conducted through an interpretive qualitative research approach in rural Bangladesh. An interpretive approach assumes that there is not just one empirical world, but everyone has their own personal views and perspectives of reality (Thiel, 2014). It typically tries to understand the social world from the perspective of individual experiences (Rossman and Rallis, 2012). Under this framework, individuals develop subjective meanings of their experiences leading the researcher to look for complex understanding rather than narrower meanings (Creswell, 2013). Any site in Bangladesh is a suitable setting for studying domestic violence for its high level of prevalence. This study was conducted in eight rural settings of Mymensingh and Netrokona administrative in Bangladesh. A majority of Bangladeshis (seventy-seven percent) live in rural areas (BBS, 2012). No study on domestic violence has ever been conducted in these districts, which was the prime motivation for doing so. Although sample size is not essential in qualitative research, it is generally important to have a reasonably good size, in order to obtain meaningful understanding from the data and its analysis (Onwuegbuzie and 
Leech, 2005 quoted in Tonsing, 2014). Moreover, the act of focusing sampling in qualitative research should be as strategic as it is practical (Mason, 2002). Keeping this in view, I selected thirty-nine victims of domestic violence, who were currently in or had been in abusive intimate relationships. In making this selection, great emphasis was placed on participants who were 'information-rich' (Hennink, Hutter, and Bailey, 2011) and therefore both purposive and snowball sampling techniques were employed in selecting them. I selected them through an array of networks: relatives, friends, government officials, NGO officials, community people, and the victims themselves who helped to select respondents. The study was conducted between August and November 2014.

The socio-demographic characteristics of the participants revealed that the average age of was twenty-eight, ranging from seventeen to fifty. The majority of the participants were from Bengali Muslim community (thirtythree), followed by Bengali Hindus (four) and the indigenous matriarchal Garo community (two). In terms of their marital status, the majority of the participants were deserted by their husbands (fourteen), separated according to their own wish (nine), living with husbands (eight), divorced (three), and husband living abroad (one). Moreover, four participants had two different types of relationship status because of being married twice. One participant was divorced by her first husband and deserted by the second husband, one was divorced by the first husband and later separated from second husband according to her wishes, one became widowed, and got married again, but was divorced, and one became widowed and was deserted by the second husband. Besides the participants that were formally divorced, the rest of them still had marital relations with their husbands on paper irrespective of their current living status.

Six were full-time salaried employees, twelve were self-employed in small businesses, and the rest were completely dependent for their livelihoods either on their husbands or other family members such as parents, brothers or sons. With regard to educational status, ten participants were illiterate, and ten literate. Only one participant had completed graduation and one had a post-graduate degree. Three participants had passed the higher secondary school examination, two participants had passed the secondary school examination, and three participants had passed the primary school examination. On the other hand, three participants had 


\section{Khan - Violence Against Rural Bangladeshi Women}

studied up to the secondary level but could not complete it, and six participants had studied up to the primary level but could not complete it. Most of the participants were married before their eighteenth birthday, which is the minimum legal age to marry for women in Bangladesh. On average, each woman had two children.

While interviewing women victims of domestic violence I was concerned about being a male researcher since disclosure about violence may be affected by many factors including the gender of the interviewer (Ellsberg, Heise, Peña, Agurto, and Winkvist, 2001). I was more careful about gaining the trust of my participants through building appropriate rapport. I developed rapport before each interview so that the barrier between the male researcher and female participant was minimised as much as possible. In all cases, I had many informal discussions with the participants and that helped to gain their trust quickly. I must admit that in some cases, I had some difficulties making them open-up to my expectations, but with my utmost efforts I could overcome most of the difficulties, and took great delight in every interview. Informed consent was obtained from all and, in accordance with the World Health Organization (WHO, 2001) guidelines, maintaining the privacy and safety of the respondents was the primary concern. Interviews were conducted, exclusively based on the choice of place and time of the respondents. Only pseudonyms were used in the reporting formats. Participation in the study was voluntary and all interviews were conducted in the local language, Bangla, and were recorded with the prior permission of the respondents. While translating into English, I was careful to record each narrative verbatim so that originality was maintained and errors remained to a minimum.

I used the thematic analytical technique in presenting the findings of the data. Specifically, the thematic analytical framework identifies and analyses themes and puts them together to form a comprehensive picture of the collective experiences of research participants (Braun and Clarke, 2006). Notably, there is no specific rule on how to develop themes, as themes can also be developed on relatively little of the data set (Braun and Clarke, 2006). I conducted the entire research process through interactive means and as such, was familiar with the data and had some initial thoughts as well in framing the themes. Audio-recorded interviews were transcribed verbatim by me. Thematic analysis demands close reading of the interviews. Although 
it was a laborious process, it gave me a firm grip of the data. I concentrated slowly and line by line on the transcribed conversations or interviews, and carefully identified the regular-recurring experiences, perceptions, and feelings of the research participants. I grouped all of the similar patterns or categories together, and picked them as "themes." The data analysis observed the following sequential but interrelated procedures: organizing data, generating categories, coding, collating codes into potential themes, defining and refining themes, and finally presenting the overall story of the different themes revealed (Marshall and Rossman, 1999). The textual presentation of the finding is done in first person "I" which articulates attention to my authorship and expresses my reflexivity and involvement as researcher.

\section{Factors of Domestic Violence}

I identified the following major factors which are very closely connected with domestic violence against rural Bangladeshi women.

\section{Dowry Demand}

The demand for a dowry was the most common factor in the perpetuation of domestic violence, and it is rooted in the social acceptance of the practice. Everybody knows that a dowry is a necessary and unavoidable condition if the parents want to get their daughters married. The majority of the women in the study reported that they were abused in a number of ways due to the demand for a dowry. The following excerpt is very significant in terms of contextualising this problem.

If Allah (God) would make a money-plant and if my husband would pluck money from it, he would be the happiest man in the world (Jhorna).

Some victims were often sent back to their family of origin following physical or mental abuse due to a dowry demand and could only go back by bringing a dowry. Some victims were either permanently sent back or forced to return to the home of origin due to excessive demand for a dowry. For some husbands, the demand for a dowry was a routine activity. They always 


\section{Khan - Violence Against Rural Bangladeshi Women}

forced their wives to bring a dowry from their parents. If they failed, they abused their wives to the extreme. Two excerpts are as follows:

When I could bring money from my brothers, he was happy. If finished, he again forced me to bring money (Sharifa).

One day my in-laws call my father, and told him to take me back. The reason was they demanded huge sums of money, which my father was unable to pay at that moment. They said send your daughter back if you can meet the demands (Seuti).

On the other hand, one of the reasons for Joita being divorced was a dowry demand. Her father failed to meet the demands of her husband and inlaws. Moreover, threatening the wife with divorce was a common weapon unless the demand a for dowry was met. Many women experienced serious physical violence due to the demand for a dowry. For example, Bristi was one of the few victims against whom finally a murder was attempted. It was because of the fact her father could not pay the demanded amount of the dowry. Bristi shared that her husband began the dreadful scene in the following way:

You have brought 100000 taka and stayed more than three years. It is more than enough. You could not bring the rest, so you must vanish. I will marry again and get more money (Bristi).

Similarly, Renu also thought that one of two main reasons (another one was extramarital relations) for attempting to murder her was the demand for 500000 taka as a dowry by her husband. Her case was interesting. Her husband did not demand any dowry during marriage. After having been engaged in an extramarital affair with his student he started demanding a dowry and abused her on those grounds so that Renu would leave him permanently. Shirin, on the other hand, had to flee from her husband's home failing to cope with the dowry demand, as she indicated in the following:

The intensity of his physical violence for demand for dowry was escalating, and he was even threatening me to kill. I thought the way he is moving at any time he might kill me. So, one morning, I fled from home (Shirin). 
Soma's husband hit her leg severely with an iron rod since she failed to bring a dowry as per her husband's expectation. He also threatened her in the following rough way:

If you find "husband" is tasty, then in order to have this taste you must buy it by fetching enough money from your father. If you fail, I would stitch your mouth for ever (Soma).

According to Hindu custom many dowries are paid to the groom during marriage, even though some Hindu participants said that the demand for a dowry of their husbands continued even after marriage. For example, during marriage, Shelekha's mother gave money to her husband and registered a piece of land in the name of Shelekha. Nevertheless, her husband abused her in many ways so that Shulekha transferred that land to her husband. Shelekha thought that one of the reasons for the disappearance of her husband was due to the fact that she did not transfer the land to his name. There were many examples in the study concerning the demand for a dowry which acted as a factor in domestic violence.

\section{Polygamy and Extramarital Relations}

"Women against women" in many ways acted as a source of domestic violence. Some participants were the victims of husbands' practices of polygamy and extramarital relations. However, these two practices were invariably linked with all of the forms of violence. In the following, I specifically present a few of the women's experiences of domestic violence caused by polygamy or extramarital relations.

The existence of another woman in Suchanda's husband's life devastated her. She got married to Shukumar in 1996. Suddenly in 2012, her husband developed a relationship with a Garo woman. On the matter of this relationship, there were many conflicts between them. Finally, he eloped with the woman. Her husband abused her in many ways. Her shop and its materials were destructed, she was deliberately sexually deprived and she was even beaten cruelly in front of many people in the market area. Amena was married in 1984. Her husband became engaged in extramarital relations with a few women after 1997. Finally, in 2007, he married a woman of her 


\section{Khan - Violence Against Rural Bangladeshi Women}

eldest daughter's age. Amena was also severely abused in many ways by her husband on the matters of conflict concerning her husband's extramarital relations and marriage. She even had to stay as a co-wife in the same house, which further brought a tremendous emotional pressure upon her. Rokeya's husband got married to another woman. When Rokeya's husband came back home permanently with his new wife, Rokeya had no option but to stay with them in the same residence. Several times her husband abused her on matters of that relationship. She remarked: "My husband said if I marry what is wrong with you? There is no harm if a man marries more than one (Rokeya)".

Molly and Bobby, two Garo women in the study, were also the victims of the husbands' extramarital affairs at some point of time. Once having had an affair with other women, their husbands abused them in many ways. Both Jinat and Shoheli came back to their family of origin with their children once their husbands got married again. Afterwards, their attempts to enter into their husbands' residences were foiled by both their husbands and their new wives. This clearly shows that nothing but polygamy kept them from attaining their own rights and the rights of their children. Hena, on the other hand, got married to a widower after being divorced by her husband. However, within a year, her new husband married three more times. She was also abused in many ways. Finally, he expelled Hena from the home. Hena remarked: "This man says that he does not keep a wife for more than a year (Hena)".

Rasu's husband maintained an illicit relationship with one of his female students. On the matter of that relationship, Rasu's husband abused her in many forms. He even seriously battered her during the period of her pregnancy, and made an attempt to murder her. In this context, I noticed another unusual example of the "women against women" syndrome. Surprisingly, the mother of that student pressured Rasu in many ways to allow her husband to marry her daughter. One day the mother of the student reacted angrily to Rasu in the following way: "You neither allow your husband to remarry nor bring dowry-so you have to find out your own ways if they marry each other (Rasu)".

On the other hand, some women unknowingly became victims of the polygamy of their husbands. When these women came to know about their husbands previous marriages and asked about them, their husbands abused 
them. For example, Tonima's husband concealed the fact that he was married twice before and had children as well. Sriti, the most educated woman in this study, unknowingly became the victim of the second wife although her husband divorced his first wife before he married Sriti. However, quite often, it was a matter of altercation between them. There were some other examples of polygamy and extramarital relationship which largely acted as a critical source of the perpetuation of violence.

\section{In-law Syndrome}

One of the common factors of domestic violence in Bangladesh is the involvement of in-laws in the perpetuation of violence. Based upon the experiences of a number of participants, it is my firm conviction that in-laws instigate, either directly or indirectly, domestic violence against women. In this research, the participants mostly reported the involvement of their mother-in-laws in such perpetuation. Regarding the involvement of the mother-in-law, Hena's comment is worth mentioning. Her husband divorced her over the phone from abroad only based on the complains of her motherin-law. "Mother-in-laws become happier if their sons cannot live with their wives and if they abuse them. This is unfortunate for women. Once women become mother-in-laws, they forget that they were daughter-in-laws as well (Hena)".

Tanni's mother-in-law stopped her education and took possession of her jewelry. She also put pressure on her to bring a dowry and many issues related to domestic chores. Most shockingly, she imposed serious stigma on the character of Tanni and created grounds for abusing her by her husband:

Until two months after my marriage, I was not experiencing any menstruation. I could not understand the reason. Nevertheless, it happened when I came home for a visit, and that created the problem. My mother-in-law became suspicious. She told that I have released my illegal foetus at my parents' home. My husband also believed that and battered me (Tanni).

Joita had to engage in all sorts of domestic chores following the day of her marriage. If her mother-in-law would find any fault, she used to scold and batter her. Moreover, she always used to speak ill of her to his son. Her 
husband used to abuse her for all those complaints made by her mother. Similarly, the mother-in-laws of Nahar, Seuti, Rosy and Shirn not only physically and mentally abused them for different purposes, but also created scope for further violence by their husbands. Nahar depicted her experience: "My mother-in-law presents a tray full with ills of me, my husband swallows (abusing her) one by one (Naahr)". Seuti also shared an interesting experience: "My mother-in-law often secretly pours fresh water and adds salt and chilli so that food becomes insipid. My husband several times battered me for that, and other in-laws scolded me as well (Seuti)".

The mother-in-laws of both Babita and Benu were unhappy since Babita was expecting to give birth to a girl child and Benu already gave birth to female twins. The mother-in-law of Babita created a situation so that she was compelled to leave the husband's house and the mother-in-law of Benu told her husband to expel her from the home.

One of the important features of the in-law syndrome was the reluctance of the in-laws to prevent their sons from abusing their wives. A number of women reported that the perpetuation of violence went high since there was no intervention from their in-laws. I conceived the idea that it was an indirect support of the in-laws to perpetuate violence. One example follows: "When I complained to my mother-in-law about violence she said if you cannot manage your husband, it is your fault, I can do nothing (Sharifa)".

However, the findings above confirm that the in-laws particularly, the mother-in-law, influenced in myriad ways the perpetuation of domestic violence against many women in the study. Such violence is a very common factor in Bangladesh since in the traditional patriarchal and patrilocal family pattern women can be subjugated very easily by their in-laws. In a patriarchal and patrilocal system a woman's life becomes very complicated, not only in terms of discharging obligations and responsibilities to other members, but also in maintaining healthy relations with them.

\section{Childless or Sonless State}

Although the above category was not applicable to all the women, some women were abused in different ways by their husbands for being childless or sonless. In Bangladesh culture, it is still highly expected that a woman will not only produce child but also male child. A woman's status increases 
in the family if she can produce a male child. A woman is solely responsible for not giving birth to a child. It is assumed that men do not have problems. For example:

Immediately after marriage, we tried to have a baby, but failed. I asked him let us go to doctor for treatment. He replied, khanki magi (daughter of prostitute), how dare you ask me to go to doctor? If I marry again then you will understand whether I have problem or not (Hena).

He took a wine bottle and said, "You say I have problem; I will insert the bottle into your area so that it would produce baby" (Pallabi).

Women whose first child was a female encountered various forms of violence, but violence on this ground at least stopped once they could produce a male child; if not, it further escalated. Rosy, Nova, Kankan, Sharifa and so on reported that their first baby was a female, and for that they had to encounter a lot of violence by their husbands and in-laws, but they became happier when the next baby was a boy. Rosy's comment is worth mentioning:

During the birth of my first baby he warned me if you give birth to a female baby, I shall divorce you-although it was a female, but thanks Allah (God), he did not do anything like that (Rosy).

Benu could not give birth to a baby for around four years. Her husband and mother-in-law in many ways abused her for that. Finally, she gave birth to twin female babies, which made her life even more problematic. Knowing about the birth of twin female babies, her husband came back from the hospital without paying the bill. Benu's father had to pay it. After a few months, her husband expelled her from the home with the babies. She said: "My condition was relatively better when I had no baby, birth of these twins have made my life bad to worse (Benu)".

Amena thought that one of the reasons for her husband having extramarital relations and finally marrying a woman was her giving birth to three consecutive female children. He also called Amena opea (woman with bad luck) for that. For Bobita, the tracing of the prospective baby's sex as a 


\section{Khan - Violence Against Rural Bangladeshi Women}

female made her life seriously miserable. She had to leave her residence due to unbearable violence during the pregnancy.

\section{Questioning Husbands}

Some women confronted violence in different ways when they had questions about the various activities and habits of their husbands. The participants reported different bad habits of their husbands such as alcohol consumption, drug addiction, gambling, bingo playing, and so on, which generated many altercations between the wife and husband. Usually, husbands do not like to be questioned by their wives and in return, they use violent means to control them. Amongst all the bad habits, gambling was reported by the participants to be the most common habit of their husbands. For example, Suchanda stated the following:

He wastes a lot of money on gambling, if I ask him to stop, he beats and bullies me. Often says, "Am I playing with your father's money? I will waste my money as the way I want. You can only ask me to stop if you bring money from home" (Suchanda).

Apart from bad habits, low income, poverty, and indifference to performing familial activities by the husbands also generated violence. The husbands were in no way ready to be questioned about their income and responsibilities. Since most of the families in the study were of lower economic status, conflict concerning low income and poverty was integral within family life. Asking for daily necessities, income, pocket money, and maintenance easily paved the way for the escalation of violence. For example: "Many times, he punished me for asking him to increase money for family expenses (Champa)".

On the other hand, I mentioned before under forms of violence that Rahiman's husband uprooted one of her teeth. He attacked Rahiman since she questioned his income. Sharifa became extremely humiliated when her husband wanted to attack her vagina with a shovel in front her younger brother following an altercation on matters of family expenses.

\section{Not Meeting Expectations}


Not meeting the husbands' and in-laws' expectations in managing domestic chores or everyday activities often triggered violence. Most of the participants reported that they were under constant pressure in terms of cooking, serving meals, childcare, care of the in-laws, attention to husbands, washing clothes, and cleaning the house. With regard to the various expectations of the husbands, the following examples are worth-mentioning:

I must make everything ready for the day before I go to school. Again, after coming from school, I have to take care for everything. I do not find rest. Even though, my mother-in-law and husband are not happy and find faults (Sriti).

I am always in a constant fix about cooking, if the food is not tasty, husband and in-laws scold me roughly. Sometimes they call me Akarmer dheki (unworth) and Baper bari hote kichu sekhe nai (nothing learnt from parents' home) (Kabita).

The behaviour of the children was always a problem for some women. The husbands used to blame the women if the children were naughty, if they did something wrong. They expected that it was a woman's responsibility to ensure proper behaviour of the children. The following excerpt of one of the participants represents the whole gamut of the husbands' expectations.

My husband does not like anything of me. Once he is at home, he only finds faults with me. If children are naughty-it is my fault; if the room is not tidy-it is my fault; if his dress is not clean-it is my fault; if the plates and glasses are not clean-it is my fault; if he does not like the food-it is also my fault. My life is full with faults. Sometimes I think my existence is also a fault (Khodeja).

In fact, there were numerous examples of the husbands' expectations regarding everyday activities like the above, which many participants considered as easy sources for perpetuating violence against them.

\section{Discussion and Conclusions}

This paper brings some important observations on domestic violence in Bangladesh. It reveals six important factors which contribute significantly in triggering domestic violence: dowry demand, in-laws syndrome, childless or 


\section{Khan - Violence Against Rural Bangladeshi Women}

sonless state of women, not meeting husbands' expectations and questioning husbands. With regard to the analysing the causes of the phenomenon, I strongly reckon that the patriarchal structure and system of the society are broadly and dominantly interwoven in every aspect of this problem, although many features of this phenomenon were also linked up with other theoretical explanations discussed in the literature review of this paper. For example, according to sociological line of thought, poverty, insufficient and low-income are strongly correlated with domestic violence. My study also found that when women asked their husbands to increase their income or provide money for family expenses, their husbands became violent. According to a psychological line of thought, the women that were critical of their husbands' performance confronted more violence. Nevertheless, specifically, within patriarchy, various forms of abuse are the tools that perpetrators use to gain control and dominate women (Dobash and Dobash, 1976), and often use them interchangeably for establishing dominance and control (Monson, Langhinrichsen-Rohling, and Taft, 2009). I assumed that the system of patriarchy promoted the structure of violence in a number of ways by subordinating women. It was out of strong Bangladeshi patriarchal ideology that the perpetrators expected that women produce a child/preferably a male child, bring a dowry for them, meet all of their expectations, and never ask questions about their activities and responsibilities. One of the most common reasons for domestic violence is the demand of a dowry (Khan, 2001). With regard to the dowry demand, my assumptions went in line with an observation made by Naved and Persson (2005), which indicated that the demand for a dowry represented the true subordinate status of women in marital relations. The practice of a dowry demand in Bangladesh, particularly among the Muslims, dates back only some decades. Previously, the malice of a dowry demand existed only in the urban and affluent classes. Over the years it has rapidly spread to rural areas and has become deeply ingrained in the poorer section of the community (Huda, 2006). Two factors are closely associated with the demand for a dowry: increased greed and the commercialisation of marriage (Farouk, 2005). A dowry is an evil customary practice in Bangladesh, although an offense under the laws of Bangladesh. However, in most cases it is even demanded after marriage by the husband and his family (Khan, 2001). The positive association between dowry demand and violence against women has 
been traced by many studies in Bangladesh as well as in India (Rao, 1997; Banarjee, 1999; Bates et al., 2004; Naved and Persson, 2005; Naved and Persson, 2010). Out of a similar patriarchal ideology, some perpetrators restricted women's mobility, mariginalised them, took control of women's economic, social, sexual and reproductive lives and decisions, and so on. I think that poverty is also behind a lot of these bad actions related to dowry demand, and of course a lack of a meaningful life. On the other hand, although my study explored the violence that is perpetrated against women by their husbands, the findings of it found that the in-laws of the victims, particularly the mother-in-law, were equally liable for both the perpetuation and provocation of violence. The mother-in-law traditionally holds power over the daughter-in-law through her position as the husband's mother (Abraham, 2000). In my opinion, such a tendency greatly promotes patriarchal interest. By doing so, women become just the enemies of women (Ganguli and Rew, 2011) and unknowingly act in favour of the structure and system of patriarchy. However, such findings are consistent with the Nepalese context where it was found that in-laws, particularly, mothers-inlaw, instigate domestic violence (Malla, Shrestha, Shrestha, Khadka, and Singh, 1999), and in the Indian context where other family members encourage or support violence (Dave and Solanki, 2000). In Bangladesh, the patrilocal residential pattern is the patriarchal norm which undermines women's autonomy (Mannan, 2002). Living in such a residential pattern, women easily become susceptible to various forms of violence by their inlaws. In my study, I found that the in-laws not only physically abused women; some male in-laws even sexually harassed them. In fact, when a married woman enters her husband's household, she assumes a weaker structural position as the daughter-in-law, subordinate to all men and senior women in the household (Kandiyoti. 1988). At the same time, my research identified much evidence, both from the women's experiences and community perceptions, of extramarital relations and practices of polygamy (permitted in Islam) as a source of different forms of violence. Such findings are consistent with the Thai findings, which state that due to the existence of "other women" in the husbands' life, many Thai women go through great troubles (Juree Vichit-Vadakan, 2000), and with the Chinese findings, which indicate that violence against women due to extramarital relations is an undisguised and unrestrained phenomenon in rural families (Wang, 1999). 
Predominantly, both of these are a symbol of the "women against women" game, which invariably promotes patriarchal interests. Specifically, in my opinion, as spouses are expected to be faithful to each other in Bangladeshi culture, men that have extramarital relations are displaying a kind of serious deviant behavior (Johnson and Das, 2009). With regard to polygamy, I assume that if polygamy is not legally stamped out completely, this system will continue to pierce the solemn structure of marital relations, and men will continue to take it for granted based on religious sanctions (Khan, 2001).

Since it is a qualitative study, carried out with a limited number of participants and in some specific areas, the findings of this study may not be necessarily generalisable to a larger audience, even though my findings can be linked and elaborated in further studies in many ways with the broader context of Bangladesh concerning domestic violence. Due to time and resource constraints it was not possible for me to include many important and pertinent aspects of domestic violence against women. It is my firm conviction is that many important areas regarding to domestic violence are still unexplored and can be investigated by future researchers. Regarding policy implications, I suggest to make a wholesale structural reform concerning women's subordination in all aspects of the society. If women's subordination can be minimised, domestic violence against women can also be eliminated. At the same time there is a need for comprehensive effort from the end of government, non-government, local groups, and international organistaions to educate people about the harms of domestic violence, and must work together against this problem (Esquivel-Santoveña, Lambert and Hamel, 2013). We have to keep in mind that it is not an individual problem, rather a social and public problem, and should be treated as such.

\section{References}

Abraham, M. (2000). Speaking the unspeakable: Marital violence among south Asian immigrants in the United States. New Brunswick, NJ:

Rutgers University Press.

Amnesty International. (2004). It's in our hands: stop violence against women. London: Amnesty International Publications. 
Banarjee, K. (1999). Gender stratification of marriage market in India. Journal of Family Issues, 648-676. doi: 10.1177/019251399020005005 Bates, L. M., Schular, S. R., Islam, F. \& Islam, M. K. (2004).

Socioeconomic factors and processes associated with domestic violence in rural Bangladesh. International Family Planning Perspectives, 30(4): 190-199. doi: 10.1363/ifpp.30.139.04

BBS. (2012). Population and housing census 2011. Bangladesh Bureau of Statistics (BBS), Ministry of Planning: Dhaka.

Bhuiya, Abbas, Sharmin, T. \& Hanifi, S.M. (2003). Nature of Domestic

Violence against Women in a Rural Area of Bangladesh: Implication for

Preventive Interventions. Journal of Health Population \& Nutrition, 21(1), 1729-1742.

Braun, V., \& Clarke, V. (2006). Using thematic analysis in psychology.

Qualitative Research in Psychology, 3, 77-101. doi:

10.1191/1478088706qp063oa

Creswell, J. W. (2013). Qualitative inquiry and research design choosing among five traditions $\left(3^{\text {rd }}\right.$ edt $)$. Thousand Oaks: Sage.

Crowell, N. A., \& Burgess, A. W. (1996). Understanding violence against women. Washington DC: National Academy Press.

Dave, A. \& Solanki, G. (2000). Special cell on women and children: A research study on domestic violence. In unnamed (summery report), Domestic Violence in India: A summary report of four studies (pp. 2533). Washington DC: International Centre for Research on Women (ICRW).

DeKeseredy, W. S., \& Schwartz, M. D. (2011).Theoretical and definitional issues in researching violence against women. In C. M Renzetti, J. L Edleson, \& R. K. Bergen (Eds.), Source book on violence against women (pp 1-20). Thousand Oaks: Sage.

Dobash, R. E., \& Dobash, R. P. (1979). Violence against Women: A case against the patriarchy. New York: Free Press.

Edwards, S. S. M. (1989). Policing domestic violence: Women the law and the state. London: Sage.

Ellesberg, M., Heise, L., Peña, R., Augurto, S., \& Winkvist, A. (2001). Researching domestic violence against women: Methodological and ethical considerations. Studies in Family Planning, 32 (1): 1-15. doi: 10.1111/j.1728-4465.2001.00001.x 
Esquivel-Santoveña, E., Lambert, T., \& Hamel, J. (2013). Partner Abuse Worldwide. Partner Abuse, 4(1), 6-75. doi: 10.1891/1946-6560.4.1.6 Farouk, S. A. (2005). Violence against women: a statistical overview, challenges and gaps in data collection and methodology and approaches for overcoming them. Geneva: UN Division for the Advancement of Women. Retrieved May 4, 2013, from http://www.un.org/womenwatch/daw/egm/vaw-stat-2005/docs/expertpapers/Farouk.pdf

Ganguli, G., \& Rew, M. (2011). Mothers-in-law against daughters-in-law: Domestic violence and legal discourses around mother-in-law violence against daughters-in-law in India. Women's Studies International Forum, 34: 420-429. doi: 10.1016/j.wsif.2011.06.006

Hattery, A. (2009). Intimate partner violence. Lanham: Rowman \& Littlefield Publishers, Inc.

Hearn, J. (1996). 'Men's violence to known women: Historical, everyday and theoretical constructions by men'. In B. Fawcett, B. Featherstone, J. Hearn \& C. Toft (eds.) Violence and gender relations-Theories and interventions. London: Sage, pp. 22-37.

Hearn, J. (1998). The violence of men. London: Sage.

Hird, M. J. (2002). Endangering violence. Ashgate: Aldershot.

Hennink, M., Hutter, I. \& Bailey, A. (2011). Qualitative research methods. London: Sage.

Huda, S. (2006). Dowry in Bangladesh: Compromising women's rights. South Asia Research, 26 (3): 249-268. doi:

10.1177/0262728006071707

Johnson, K. B., \& Das, M. B. (2009). Spousal violence in Bangladesh as reported by men: Prevalence and risk factors. Journal of Interpersonal Violence, 24 (6): 997-995. doi: 10.1177/0886260508319368

Johnston, H. B., \& Naved, R. T. (2008). Spousal violence in Bangladesh: A call for a public-health response. Journal Health Population Nutrition, 26 (3): 366-377. doi: 10.3329/jhpn.v26i3.1903

Juree Vichit-Vadakan (2000). Violence against women: A Thai perspective. Bangkok: Centre for Philanthropy and Civil Society, NIDA.

Kandiyoti, D. (1988). Bargaining with patriarchy. Gender and Society, 2: 274-290. 
Kelly, L. (1996). Tensions and possibilities: Enhancing informal responses to domestic violence. In J. L. Edleson, \& Z. C. Eisikovit (Eds.), Future interventions with battered women \& their families: Sage series on violence against women volume III (pp. 67-86). Thousand Oaks: Sage.

Khan, S. R. (2001). The socio-legal status of Bengali women in Bangladesh: Implications for development. Dhaka: UPL.

Khatun, T \& Rahman, K. F. (2012). Domestic violence against women in Bangladesh: Analysis from a socio-legal perspective, Bangladesh eJournal of Sociology, 9 (2): 19-29.

Koenig, M. A., Ahmed, S., Hossain, M.B. \& Khorshed, A. M. A. B. (2003).

Women's status and domestic violence in rural Bangladesh: Individual and community level effects. Demography, 40 (2): 269-288.

Levy, B. (2008). Women and violence. Berkeley, CA: Seal Press.

Mannan, M. A. (2002). Violence against women: Marital violence in rural

Bangladesh. Dhaka: Centre for Policy Dialogue. Retrieved April 12,

2013, from http://www.cpd-

bangladesh.org/publications/cpdunfpa/unfpa20.PDF

Malla, S.P., Shrestha, I., Shrestha, A., Khadka, B., \& Singh, I. (1999).

Violence against women and girls in Nepal. In In F. M. Cheng, M.

Karlerker, A. D. Dios, Juree Vichit-Vadakan \& L. R. Quisumbing (Eds.),

Breaking the Silence: Violence against Women in Asia (pp 139-151).

Hong Kong: Equal Opportunities Commission.

Marshall, C. \& Rossman, G. B. (1999). Designing qualitative research ( $1^{\text {st }}$

$E d s)$. Thousand Oaks: Sage.

Maynard, M. \& Winn, J. (1997). Women, violence and male power. In V.

Robinson \& D. Richardson (Eds.), Introducing women's studies (pp. 175197). Basingstoke: Palgrave.

Mason, J. (2002). Qualitative researching. London: Sage.

McCue, M. L. (2008). Domestic violence-A reference handbook. Santa Barbara: ABC-CLIO, Inc.

Monson, C. M., Langhinrichsen-Rohling, J., \& Taft, C. T. (2009) Sexual aggression in intimate relations. In O'Leary, K. D. \& Woodin, E. M. (Eds.), Psychological and physical aggression in couples: causes and interventions (pp. 37-58). Washington D.C: American psychological Association. 
Moony, J. (2000). Gender, violence and social order. Basingstoke: Macmillan Press.

Naved, R. T. (2013). Sexual violence towards married women in Bangladesh. Archives of Sexual Behaviour, 42: 595-602. doi: 10.1007/s10508-012-0045-1

Naved, R. T., \& Persson, L. A. (2005). Factors associated with spousal physical violence against women in Bangladesh. Journal of Family Planning, 36 (4): 289-300. doi: 10.1111/j.1728-4465.2005.00071.x

Naved, R. T., \& Persson, L. A (2010). Dowry and spousal physical violence women in Bangladesh. Journal of Family Issues, 31 (6): 830-856. doi: 10.1177/0192513X09357554

Perillia, J. L., Lippy, C., Rosales, A., \& Serrata, J.V. (2011). Prevalence of domestic violence. In J. W. White, M. P. Koss, \& A. E. Kazdin (Eds.). Violence against women and children: Mapping the terrain (Vol.1) (pp.199- 220).Washington D.C: American Psychological Association. Rao, V. (1997). Wife-beating in rural south India: A qualitative and econometric analysis. Social Science \& Medicine, 44, 1169-1180. doi: 10.1016/S0277-9536(96)00252-3

Richardson, J., Coid, J., Petruckevitch, A., Chung, W. S., Moorey, S., \& Feder, G. (2002). Identifying domestic violence: Cross-sectional study in primary care. British Medical Journal, 324: 274-277. doi:

10.1136/bmj.324.7332.274

Romito, P. (2008). A deafening silence: Hidden violence against women and children. Bristol: The Policy Press.

Rossman, G. B. \& Rallis, S. F. (2012). Learning in the field: An introduction to qualitative research. Thousand Oaks: Sage.

Salam, A., Alim, A. \& Noguchi, T. (2006). Spousal abuse against women and its consequences on reproductive health: A study in the urban slums in Bangladesh. Maternal and Child Health Journal, 10 (1): 83-94. doi: 10.1007/s 10995-005-0030-6

Schular, S. R., Hashemi, S.M., Riley, A. P., \& Akhter, S. (1996). Credit programs, patriarchy and men's violence against women in rural Bangladesh. Social Science and Medicine, 43 (12): 1729-1742. doi: 10.1016/S0277-9536(96)00068-8

Siddiqi, D. M. (2006). One step forward, two steps back? Women's rights in 2005. In H. Hossain (Ed.), Human rights in Bangladesh 2005 (pp. 197216). Dhaka: Ain o Salish Kendra (ASK). 
Skinner, T., Hester, M., \& Malos, E. (2005). Researching gender violence:

Feminist methodology in action. Abingdon: Willan.

Stacey, J. (1993). Untangling feminist theory. In V. Robinson \& D.

Richardson (Eds), Introducing women's studies (pp. 49-73). Basingstoke:

Palgrave.

Thiel, S. V. (2014). Research methods in public administration and public management. London: Routledge.

Tonsing, J. C. (2014). A study of domestic violence among south Asian women in Hong Kong (Doctoral dissertation). Centre for Criminology and Sociology, University of London. Retrieved December 6, 2014 from https://pure.royalholloway.ac.uk/portal/files/19440165/Jenny_thesis_PhD _2014_.pdf

Wang, X. (1999). Domestic violence in china. In F. M. Cheng, M. Karlerker, A. D. Dios, Juree Vichit-Vadakan, \& L. R. Quisumbing (Eds.), Breaking the Silence: Violence against Women in Asia (pp. 13-37). Hong Kong: Equal Opportunities Commission.

Walby, S. (1996). The 'declining significance' of the 'changing forms' of patriarchy? In V. M. Moghadam (Ed.), Patriarchy \& economic development: Women's positions at the end of the twentieth century ( $\mathrm{pp}$. 19-33). Oxford: Clarendon.

WHO (2001). Putting Women First: Ethical and Safety Recommendations for Research on Domestic Violence Against Women. Geneva: World Health Organisation. Retrieved March 12, 2012 from http://www.who.int/gender/violence/womenfirtseng.pdf.

Women's Aid (2009). Domestic violence: Frequently asked questions factsheet 2009. Retrieved February 21, 2013, from http://www.womensaid.org.uk/domestic-violencearticles.asp?section $=00010001002200410001 \&$ itemid $=1272$

Yodanis, C, L. (2004). Gender inequality, violence against women and fear: A cross-national test of feminist theory of violence against women. Journal of Interpersonal Violence, 19 (6): 655-675. doi:

$10.1177 / 0886260504263868$

Anisur Rahman Khan Assistant Professor in the Department of Social Relations at East West University.

Contact address: Department of Social Relations. A/2, Jahurul Islam City Gate, 1212, Aftab Nagar Main Rd, Dhaka, Bangladesh 
1231 Khan - Violence Against Rural Bangladeshi Women 